\title{
Serum Tumor Necrosis Factor-Alpha (TNF- $\alpha$ ) Levels in Children with Nephrotic Syndrome and Its Correlation with Biochemical Parameters
}

\author{
Ammar B. Al-Assadi ${ }^{1 *}$, Nidhal A. Mohammed ${ }^{1}$ and Shatha H. Ali ${ }^{2}$ \\ ${ }^{1}$ College of Biotechnology, Al-Nahrain University, Iraq \\ ${ }^{2}$ College of Medicine, Al-Nahrain University, Iraq \\ *Corresponding author
}

\section{A B S T R A C T}

\section{Key words \\ ELISA, SSIFR, SSFR, SR \\ Article Info \\ Accepted: \\ 24 August 2018 \\ Available Online: \\ 10 September 2018}

The aim of this study is to compare the levels of TNF- $\alpha$ in children with nephrotic syndrome and healthy control children and the correlation of TNF- $\alpha$ with clinical feature of NS. Fifty children with NS were divided into four groups: 14 steroid sensitive infrequent relapse (SSIFR), 12 steroid sensitive frequent relapse (SSFR), 9 steroid resistance (SR) and 15 newly diagnosis (ND) compared to twenty-five unrelated healthy children. The serum IL-13 levels for NS patients and healthy control children were measured by R\&D quantitative ELISA kit. Serum levels of TNF- $\alpha$ showed highly significant difference between patients with NS $(15.68 \pm 2.38 \mathrm{pg} / \mathrm{ml})$ and healthy control $(1.066 \pm 0.65 \mathrm{pg} / \mathrm{ml})$, and there is no significant different among NS groups. Highly significant correlation between TNF- $\alpha$ mean level and biochemical markers of NS patients also reported in this study.

\section{Introduction}

Nephrotic syndrome is an immune mediated renal disease. It is related with dysfunction of $\mathrm{T}$-cell and secondary disorder of B-cell that leads to changes in scales of immunoglobulins (Roy et al., 2009; Bahbah et al., 2015). This systemic disturbance of function of $\mathrm{T}$ cell results in the production of humoral factors or lymphokines that responsible for the rise of permeability of glomerular basement membrane (Sahali et al., 2002; Bagga et al., 2005). Nephrotic syndrome is described by huge proteinuria, edema and hypoalbuminemia, the additional features are hyperlipidemia also generally present (Bahbah et al., 2015). Hypercoagulable status, the dysregulation of fluid, imbalance in electrolyte and capability to infections can caused by large urinary wastage of serum proteins (Kim et al., 2016). Estimates on the annual incidence of nephrotic syndrome range from two to seven per 100,000 children, and prevalence from twelve to sixteen per 100,000 (Eddy and Symons, 2003). Cytokines are functional class of tiny proteins and glycoprotein (molecular weights of approx. 8$80 \mathrm{kDa}$ ) and fundamentally they are monomers that function as soluble mediators in an autocrine or paracrine manner. Cytokines are produced by a number of cell types, predominantly leukocytes, and their targets implicate both immune and nonimmune cells (Sivangala and Sumanlatha, 
2015). Based on their production of cytokine, T-helper lymphocytes can be divided into two types: Th1 and Th2 cells. Th1 cells typically produce TNF (tumour necrosis factor), interleukin-2 (IL-2) and IFN- $\gamma$ (interferon- $\gamma$ ), which activate cytotoxic and inflammatory reactions. While Th 2 cells produce IL-4, IL-5, IL-6, IL-10 and IL-13, which are associated with the strong antibody regulation and allergic responses (Jafar et al., 2011; Mohammed et al., 2015).

Studies on in vitro mitogen-stimulated cytokines production by PBMC from idiopathic NS children have demonstrated an increased production of various cytokines, including IL-1, IL-2, IL-4 and TNF- $\alpha$, compared with patients in remission or with healthy subjects (Berg and Weening, 2004). There is elevated production of IL-12 and IL18 by PBMC from MCNS children and reduced production of IL-1 and IL-10 compared with normal controls. To circumvent artefacts induced by stimulation with mitogens, the unstimulated cytokines production by MCNS patients T-lymphocytes and found an elevated production of IL-13, whereas production of IL-4 was normal (Berg and Weening, 2004). Tumor necrosis factoralpha $(\mathrm{TNF} \alpha)$ is a cytokine secreted from $\mathrm{T}$ cells and macrophages and has multiple immunological functions (Yang, 2015). It is inflammatory mediator that is focal to the inflammatory action of the innate immunity induction: production of cytokine, activation of adhesion molecules, and growth energizing (Turner, 2014). The TNF- $\alpha$ soluble form is cleaved from transmembrane TNF- $\alpha$. It binds to TNF receptor (TNFR) and transfers intracellular signals through TNFR-associated factors (Yang, 2015). TNFR divided into two types (TNFR1 and TNFR2). TNFR1 is found on all types of cells, while TNFR2 is expressed only on immune system cells (Fischer and Maier, 2015). TNFR1 ligation catalyzes biological function such as induction of $(\mathrm{NF}-\mathrm{\kappa} \mathrm{B})$ system, the triggering of mitigenactivated protein kinase (MAPK)transduction signaling cascades (Galluzzi et al., 2012; Vandenabeele et al., 2010). TNF- $\alpha$ affect the expression of nephrin and podocyte cytoskeletal rearrangement (Rong et al., 2017).

TNF- $\alpha$ exerts inflammation, apoptosis and proliferation (Shaikh, 2011). TNF- $\alpha$ can stimulate fever, either directly through stimulation of PGE2 synthesis by the vascular endothelium of the hypothalamus, or indirectly by prompting release of IL-1. TNF$\alpha$ can catalyze the production of PGE2 and collagenase by synovial cells and thus are believed to contribute to harm of joint in inflammatory conditions such as rheumatoid arthritis, TNF- $\alpha$ also shares a substantial inflammatory property with IL-6 and IL-11 (Shaikh, 2011). TNFa mRNA High concentration and elevated TNF- $\alpha$ protein production from monocytes of children with active idiopathic NS, relative to patients in remission, and healthy individual were observed (Bustos et al., 1994).

\section{Patients and Methods}

Fifty blood samples of patients suffering from nephrotic syndrome during the period from September 2017 to January 2018 from the AlEmamain Al-Kadhemain Teaching hospital and Welfare Teaching hospital in medical city of Baghdad and twenty-five blood samples have been collected from unrelated healthy children. The age of NS patients was from 2 to 14 years with mean $7.78 \pm 3.52$ years and from 5 to 14 years with mean $8.64 \pm 3.08$ years for healthy control. Out of 50 cases, 35 cases (70\%) were males and 15 cases (30\%) were females and the male to female ratio was 2.3:1. Pathological types based on response to steroid nephrotic syndrome among patients revealed that 14 cases $(28 \%)$ steroid sensitive infrequent relapse (SSIFR), 12 cases $(24 \%)$ 
steroid sensitive frequent relapse (SSFR), 9 cases (18\%) steroid resistance (SR) and 15 cases (30\%) newly diagnosis (ND). The biochemical test was done to determine the levels of blood urea, serum creatinine, serum albumin and serum cholesterol in patients and healthy control. Serum TNF- $\alpha$ levels were detected for NS patients and healthy control by using R\&D ELISA kit.

The Statistical Analysis System- SAS (2012) program was used to effect of difference factors in study parameters. Chi-square test was used to significant compare between percentage and least significant difference LSD test (ANOVA) or T-Test was used to significant compare between means. Estimate of correlation coefficient between variables in this study.

\section{Results and Discussion}

Fifty children with NS compared to twentyfive healthy children as a control group were recorded in this study. Pathological types based on response to steroid nephrotic syndrome among patients revealed that 14 cases $(28 \%)$ steroid sensitive infrequent relapse (SSIFR), 12 cases (24\%) steroid sensitive frequent relapse (SSFR), 9 cases (18\%) steroid resistance (SR) and 15 cases (30\%) newly diagnosis.

The mean level of serum albumin, serum creatinine and blood urea was significantly decreased in patients in compared with healthy control, while the mean level of urine albumin and serum cholesterol was significantly increased in patients in compared with healthy control. The results of mean TNF- $\alpha$ level in healthy serum $(1.066 \pm 0.65 \mathrm{pg} / \mathrm{ml})$ was significantly lower than children with nephrotic syndrome $(15.68 \pm 2.38 \mathrm{pg} / \mathrm{ml})$ (Table 1).

Comparison between the TNF- $\alpha$ concentration among types of NS and healthy control demonstrated that insignificant difference between ND $(15.03 \pm 2.39 \mathrm{pg} / \mathrm{ml})$, SR $(14.39$ $\pm 1.14 \mathrm{pg} / \mathrm{ml})$, SSFR $(14.75 \pm 3.64 \mathrm{pg} / \mathrm{ml})$ and SSIR $(18.01 \pm 7.71 \mathrm{pg} / \mathrm{ml})$ (Figure 1).

This study showed a highly significant $(\mathrm{P}<0.01)$ correlation between serum TNF- $\alpha$ levels and Serum albumin, proteinuria and $\mathrm{RBCs}$ in urine of the nephrotic groups.

There was a significant $(\mathrm{P}<0.05)$ correlation between TNF- $\alpha$ and Urea level in NS patient. No significant correlation was reported for TNF- $\alpha$ with Creatinine and pus cell in urine (Table 2).

Increased levels of TNF- $\alpha$ was agreed with Suranyi et al., (1993) which reported that TNF- $\alpha$ was found to be significantly increased in the plasma and urine of patients with nephrotic syndrome above that found in healthy control.

Elevated levels of TNF- $\alpha$ were found in supernatant of culture of mitogen-stimulated mononuclear cells of peripheral blood from infected children with FSGS. Four out of ten children with primary FSGS showed remission of proteinuria in a (phase I) trial of a TNF $\alpha$-neutralizing antibody (Bierzynska and Saleem, 2017).

Bitzan et al., (2012) showed that TNF- $\alpha$ pathway dependent alteration in podocyte cytoskeletal alterations and also alterations in focal adhesion complexes of podocyte.

TNF- $\alpha$ interacts with 2 different receptors, specifiedTNFR1 and TNFR2, which are differentially expressed on tissues and cells and begin both distinct and overlapping pathways of signal transduction (Bradley, 2008). These varied signaling cascades progress to a range of cellular responses, inclusive survival, migration, proliferation, differentiation and death of cell. 
Table.1 Compare between patients and control in TNF- $\alpha$ levels

\begin{tabular}{|c|c|}
\hline Group & Mean \pm SE \\
\hline Patients & $15.68 \pm 2.38$ \\
\hline Control & $1.066 \pm 0.65$ \\
\hline T-Test & $6.820 * *$ \\
\hline P-value & 0.0001 \\
\hline & $* * 0.01)$. \\
\hline
\end{tabular}

Table.2 Correlation between TNF- $\alpha$ and diagnostic features in patients

\begin{tabular}{|c|c|}
\hline Laboratory parameters for diagnosis NS & TNF- $\alpha$ \\
\hline Urea & $-0.21 *$ \\
\hline Creatinine & $-0.15 \mathrm{NS}$ \\
\hline Serum albumin & $-0.43 * *$ \\
\hline Cholesterol & $0.16 \mathrm{NS}$ \\
\hline Urine albumin & $0.29 * *$ \\
\hline Pus cell in urine HPF & $-0.11 \mathrm{NS}$ \\
\hline RBC in urine HPF & $0.46 * *$ \\
\hline$*(\mathbf{P}<0.05), * *(\mathbf{P}<0.01)$, NS: Non-Significant. \\
\hline
\end{tabular}

Fig.1 Serum TNF- $\alpha$ levels among groups of NS and control

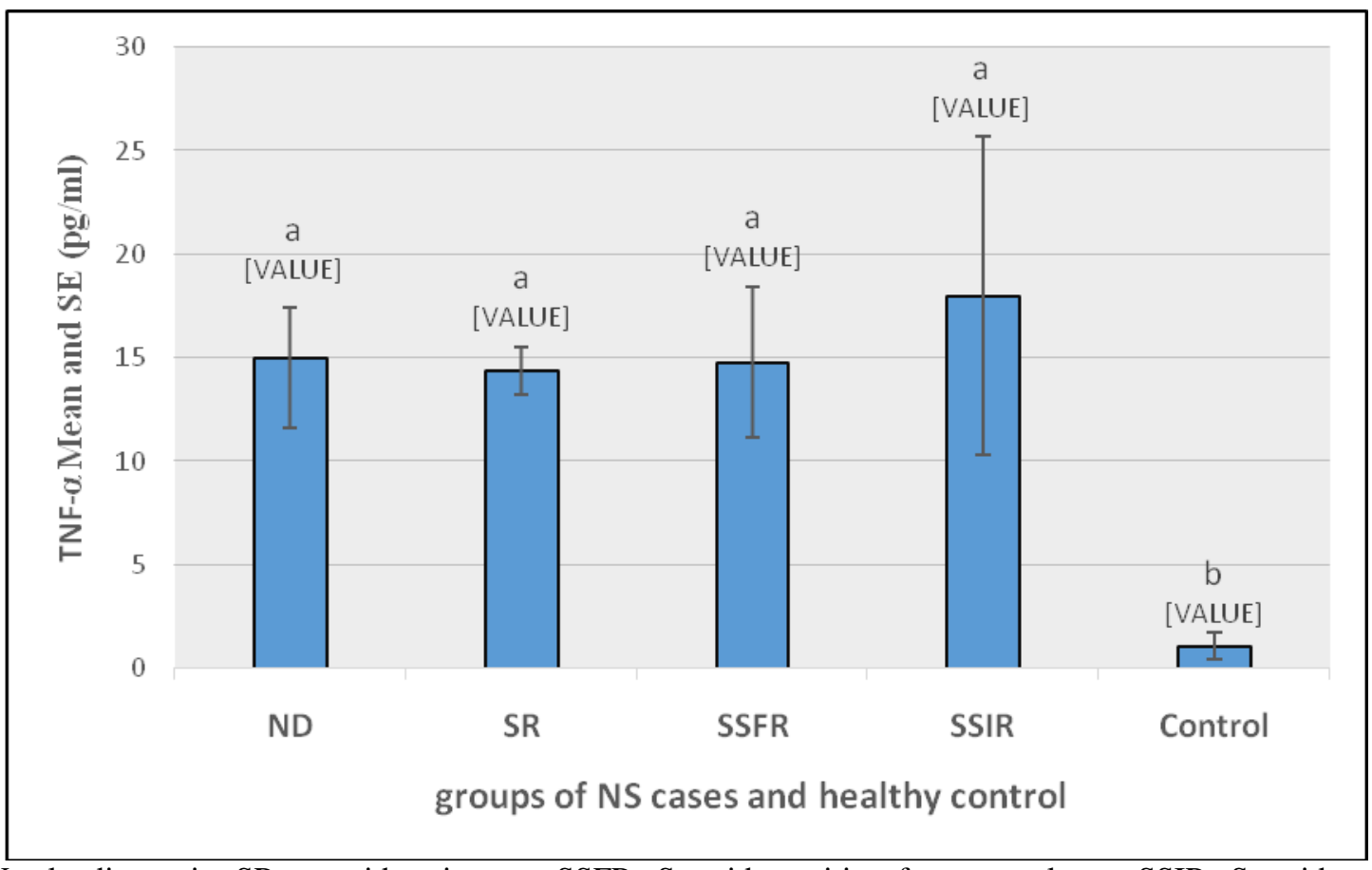

ND: Newly diagnosis, SR: steroid resistance, SSFR: Steroid sensitive frequent relapse, SSIR: Steroid sensitive infrequent relapse. Different letters mean significant differences between means at $\mathrm{P}<0.01$ 
Vascular endothelial cells comply to TNF- $\alpha$ by a number of pro-inflammatory changes which rise white blood cells adhesion, vascular permeability and trans endothelial migration, and may thrombosis promoting. The central role of TNF- $\alpha$ in inflammation has been elucidated by the successful use of TNF- $\alpha$ blocking agents in the therapy of many inflammatory conditions, like rheumatoid arthritis, inflammatory bowel disease, ankylosing, psoriasis and spondylitis (Lonaki et al., 2009).

Nephrotic syndrome recurrence is linked with glucocorticoid receptor (GR) expression levels, overexpression of GR $\beta$ and decrease inGR $\alpha$ expression. Renal syndrome is caused by numerous factors, including infections, which may trigger the return of renal syndrome by inducing the glucocorticoid receptor to alter the efficiency of glucocorticoid (GC). Immunological inflammatory interface and transcription factors are pivotal to the organizing of GRmediated GC efficacy. Various inflammatory response exciter are able to minimize or even prevent the binding of glucocorticoid to target cells. This episode is the clinical cause for return nephrotic syndrome. Infection is the most prevalent reason of relapse. Components of Bacterial cell, including lipopolysaccharide and lipoteichoic acid, are capable to stimulate themonocyte/macrophage intra cellular indicative transduction pathways and prompt the transcription and overexpression of TNF$\alpha$ encoding genes. During the precocious phases of inflammation, TNF-amay play as a key medium to activate the downstream factors expression, including $K$-IFN, IL-1, IL2, IL-4and IL-8 and thus start a cascade reaction, which then promotes the nephrotic syndrome return by affecting glucocorticoid response (Liang et al., 2015).

Liang et al., (2015) also reported that TNF- $\alpha$ may also induce the decrease or even inhibition of glucocorticoid activity and therefore directly affect the glucocorticoid receptor. The serum concentration of TNF- $\alpha$ in patients with nephrotic syndrome return were significantly higher compared with those in the normal groups. This proposes that elevated serum levels of TNF- $\alpha$ are associated with the nephrotic syndrome recurrence.

Berghea et al., (2017) reported many studies that tried to recognize the circulating factors released from T-lymphocyte that elevate the glomerular permeability to serum albumin. elevated levels of IL-2, soluble IL-2 receptor, IL-4, IL-12, IL- 13, IL-18, tumor necrosis factor (TNF)- $\alpha$, and vascular endothelial growth factor (VEGF) were related with MCD relapse. The specific action of a cytokine on the proteinuria development was not studied extensively. Using an animal model, Laflam and Garin (2006) recorded a significant elevated in albuminuria in rats following infusion of TNF- $\alpha$.

Conclusion: increased serum TNF- $\alpha$ concentration in children with NS and there is high correlation between its level and decrease serum albumin and elevate serum cholesterol. Further studies of the effect of TNF- $\alpha$ in the kidney in children with NS and the effect of TNF- $\alpha$ on permeability of glomeruli are needed.

\section{References}

Bagga, A. and Mantan, M. (2005). Nephrotic syndrome in children. Indian J. Med. Res., 122(1):13-28.

Bahbah, M., El Mashad, G., Abdelnaby, S. and Azab, H. (2015). Serum immunoglobulin $\mathrm{G}, \mathrm{M}$ and $\mathrm{IgG}$ : $\mathrm{IgM}$ ratio as predictors for outcome of childhood nephrotic syndrome. Menoufia medical J., 28: 431-436.

Berg, J. and Weening, J. (2004). Role of the immune system in the pathogenesis of 
idiopathic nephrotic syndrome. Clin. Sci., 107(2): 125-136.

Berghea, E., Balgradean, M. and Popa, L. (2017). Correlation between idiopathic nephrotic syndrome and atopy in Children - Short Review. Maedica (Buchar), 12(1): 55-58.

Bierzynska, A. and Saleem, M. (2017). Recent advances in understanding and treating nephrotic syndrome. F1000 Res., 6: 121.

Bitzan, M., Babayeva, S., Vasudevan, A., Goodyer, P. and Torban, E. (2012). $\mathrm{TNF} \alpha$ pathway blockade ameliorates toxic effects of FSGS plasma on podocyte cytoskeleton and $\beta 3$ integrin activation. Pediatr. Nephrol., 27(12): 2217-2226.

Bradley, J. (2008). TNF-mediated inflammatory disease. J. pathol., 214: 149-160.

Bustos, C., Gonzaleze, E., Muley, R., Alonso, J. and Egido J. (1994). Increase of tumor necrosis factor $\alpha$ synthesis and gene expression in peripheral blood mononuclear cells of children with idiopathic nephrotic syndrome. Eur. J. Clin. Invest., 24: 799-805.

Eddy, A. and Symons, J. (2003). Nephrotic syndrome in childhood. The Lancet J., 362:629-639.

Fischer, R. and Maier O. (2015). Interrelation of oxidative stress and inflammation in neurodegenerative disease: role of TNF. Hindawi Publishing Corporation Oxidative Medicine and Cellular Longevity, Volume 2015, Article ID 610813, 18 pages

Galluzzi, L., Vitale, I., Abrams, J., Alnemri, E., Blagosklonny, M., Dawson, V., ElDeiry, W., Fulda, S., Gottlieb, E., Green, D., Hengartner, M., Kepp, O., Knight, R., Kumar, S., Lipton, S., Lu, X., Madeo, F., Malorni, W., Mehlen, P., Nunez, G., Peter, M., Piacentini, M., Rubinsztein, D., Shi, Y., Simon, H.,
Vandenabeele, P., White, E., Yuan, J., Zhivotovsky, B., Meline, G. and Kroemer, G. (2012). Molecular definition of cell death subroutines: recommendations of the nomenclature committee on cell death 2012. Cell Death Differ., 19(1): 107-120.

Jafar, T., Agrawal, S., Mahdi, A., Sharma, R., Awasthi, A. and Agarwal, G. (2011). Cytokine gene polymorphism in idiopathic nephrotic syndrome children. Ind. J. Clin. Biochem., 26(3): 296-302.

Kim, S., Park, S., Han, K., Kronbichler, A., Saleem, M., Oh, J., Lim, B. and Shin, J. (2016). Pathogenesis of minimal change nephrotic syndrome: an immunological concept. Korean J. Pediatr., 59(5): 205211.

Liang, Y., Chen, Y., Chen, Y. and Gong, Y. (2015). Role of the glucocorticoid receptor in the recurrence of primary nephrotic syndrome. Exp. Ther. Med., 10(4): 1556-1562.

Lonaki, S., Siamopoulos, K., Theodorou, I., Bertsias, G., Boumpas, D. and Boletis, J. (2009). Inhibition of tumour necrosis factor alpha in idiopathic membranous nephropathy: a pilot study. Nephrol. Dial. Transplant., 24(7): 2144-2150.

Mohammed, D., Elbehidy, R., El-Shal, A. and Sherief, L. (2015). T helper 1 and $T$ helper 2 cytokine in atopic children with steroid-sensative nephrotic syndrome. Iranian J. Kid. Diseases, 9(3): 298-304.

Rong, C., Wenyan, L., Yuanyuan, W. and Jian, G. (2017). Advances and researches in idiopathic nephrotic syndrome biomarkers. MOJ Women Health, 5(1): 00110.

Roy, R., Roy, E., Rahman, M. and Hossain, M. (2009). Serum immunoglobulin G, $\mathrm{M}$ and $\mathrm{IgG}$ : $\operatorname{IgM}$ ratio as predictors for outcome of childhood nephrotic syndrome. World J. Pediatr, 5(2):127131. 
Sahali, D., Lang, P., Guellaen, G. and Bensman, A. (2002). New insights about immunopathology of lipoid nephrosis. Bull Acad. Natl. Med., 186:683-690.

SAS. (2012). Statistical Analysis System, User's Guide. Statistical. Version $9.1^{\text {th }}$ ed. SAS. Inst. Inc. Cary. N.C. USA.

Shaikh, P. (2011). Cytokines \& their physiologic and pharmacologic functions in inflammation: A review. Int. J. of Pharm. \& Life Sci., 2(11): 1247-1263.

Sivangala, R. and Sumanlatha, G. (2015). Cytokines that mediate and regulate immune responses. Austin publishing group, 1-26.
Suranyi, M., Guasch, A., Hall, B. and Myers, B. (1993). Elevated levels of tumor necrosis factor-alpha in the nephrotic syndrome in humans. Am. J. Kidney Dis., 21(3): 251-259.

Turner, M., Nedjai, B., Hurst, T. and Pennington, D. (2014). Cytokines and chemokines: at the crossroads of cell signaling and inflammatory disease. Biochim. Biophys. Acta., 1843(11): 2563-2582.

Vandenabeele, P., Galluzzi, L., Berghe, T. and Kroemer G. (2010). Molecular mechanisms of necroptosis: an ordered cellular explosion. Nat. Rev. Mol. Cell Biol., 11: 700-714.

Yang, Y. (2015). TNF $\alpha$ in liver fibrosis. Springer, 3(4): 253-261.

\section{How to cite this article:}

Ammar B. Al-Assadi, Nidhal A. Mohammed and Shatha H. Ali. 2018. Serum Tumor Necrosis Factor-Alpha (TNF- $\alpha$ ) Levels in Children with Nephrotic Syndrome and Its Correlation with Biochemical Parameters. Int.J.Curr.Microbiol.App.Sci. 7(09): 3464-3470. doi: https://doi.org/10.20546/ijcmas.2018.709.429 